\title{
The Other Great Chinese Trepitaka in Japan: Faxian as Translator and Pilgrim in Medieval Japanese Manuscript Canons
}

\author{
GEORGE A. KEYWORTH \\ University of Saskatchewan \\ george.keyworth@usask.ca
}

Keywords: Faxian, old Japanese manuscripts, Chinese Buddhism, Chinese pilgrims to India, Faxian's translations

DOI: https://dx.doi.org/10.15239/hijbs.02.01.04

Abstract: In what we may call the standard Sino-Japanese Buddhist canons of the medieval period in East Asia, two distinct biographies of eminent Chinese trepitakas and pilgrims to India, Xuanzang 玄牀 (Genjō, c. 602-664) and Faxian 法顯 (Hōgan, 337-ca. 422), figure prominently. Xuanzang enjoyed considerable repute in Japan since the establishment of Kofukuji 興福寺 in Nara, by the powerful Fujiwara 藤原 family in the late seventh century. Little attention has been paid, however, to the notoriety of Faxian in Japan, where curious twelfth century copies of eighth century versions of his biography, Gaoseng Faxian zhuan 高僧法顯傳 ( $Z$ no. 1194, T no. 2085), are preserved within only three of the eight extant manuscript canons (Shōgozō 聖語藏, Nanatsudera 七寺一切經, Matsuo shrine 松尾社 一切經). In this paper I investigate the provenance of these early and reliable manuscript editions of the Faxian zhuan, and reveal some of the textual differences between printed, received editions of this account of Faxian's life and travels and these Japanese texts. Through analysis of colophons to Faxian's translations of the Mabāyāna Mabāparinirvānā-sūtra (Da bannibuan jing 大般泥洹經, $Z$ no. 137, 
$T$ no. 376) and the so-called non-Mahāyāna version (Da banniepan jing 大般涅槃經, $Z$ no. 774, $T$ no. 7), which were widely一and explicitly_circulated in medieval Japan among Nara 南都六宗, Shingonshū 真言宗, and Tendai 天台宗 Buddhists, it is evident that the legacy of Faxian as an archetypal pilgrim, translator, and teacher may rival apparent admiration for Xuanzang in medieval Japan.

\section{On Approaching Trepițakas, the Tripițaka, and Pilgrims in Search of the Dharma}

here is ample evidence from early European studies of Buddhism
that Chinese Buddhism is distinctive because of three particular pilgrims who traveled to India in search of sacred scriptures (qiufa gaoseng 求法高僧): Faxian (journey: 399-412 or 413), Xuanzang (journey: 629-645), and Yijing 義凈 (635-713, journey: 671-694). Why else would Giuseppe Tucci, writing in 1933 about one of the most famous Tibetan translators lotsawas (lo $T s a$ ba), Rinchen Zangpo (rin chen bzan po, 958-1055), have made such a curious statement about religious exchanges during the tenth and eleventh centuries between the Spiti valley in India and western Tibet (Gu ge)?

This was a wonderful period in which Buddhist masters did not disdain to help their Tibetan brothers, who full of faith and mystical ardour descended their steep mountains and did not hesitate in confronting dangers and discomforts of the Himalayan passes, submitted with resignation to the hardships that a stay in the hot and humid Indian plains induced; messengers and apostles of religion and civilization who renewed with equal daring the example of the Chinese Buddhist pilgrims. Of this multitude of translators only names remain. ${ }^{1}$

Unless we can assume that Tucci read in some arcane Tibetan commentary about how a lama (bla ma) praised Chinese pilgrims

$1 \quad$ Tucci, Rin-chen-bzan-po, 37. 
or cited one of the Chinese accounts of the travels of Faxian, Xuanzang, Yijing, or another eminent pilgrim, or perhaps he saw a mural with a Chinese pilgrim on it during his expeditions in the western Himālayas, I suspect that as a Sinologist and a specialist in the study of Indian and Tibetan religion Tucci read several of the early, chilling European language translations of these three monks' voyages across western China, central Asia, and India. ${ }^{2}$ Although the chronology does not match up with Rémusat's 1836 translation of Faxian's Autobiography of the Eminent Monk Faxian (Gaoseng Faxian zhuan 高 僧法顯傳, $Z$ no. 1194, $T$ no. 2085, 51: 857a2-866c6)—also known as Record of Buddhist Kingdoms (Foguo ji 佛國記)—in one roll, it stands to reason that apart from [Protestant] missionizing activities in China, the reason so much attention was awarded to these three eminent Chinese pilgrims is because they enjoyed a remarkable status in Japan.

In Arthur Waley's The Real Tripitaka, in between discussing several surly letters Xuanzang sent to cohorts he had met at Nālandā after he returned to China and an apparent controversy over whether or not secular officials could grasp the profundity of his translations of Dignāga's Nyāyapraveśa (Yinming ruzhengli lun 因明入正理論, $Z$ no. 726, T no. 1630) and Nyāmukha (Yinmine zhenglimen lunben 因明正理門論本, $Z$ no. $724, T$ no. 1628), cites a Japanese historical record, the Shoku Nihongi 続日本紀 (comp. 797), to describe how the young monk Dōshō 道昭 (629-700, in China 653-660) met Xuanzang and received a small cooking pot (or kettle) as a gift from him. ${ }^{3}$ The casual reader might presume that Dōshō is mentioned in A Biography of the Tripitaka master of the Great Cien monastery of

2 On Faxian, see Klaproth, Clerc de Landresse, and Rémusat, Foé Koué Ki; Legge, A Record of Buddhistic Kingdoms. On Xuanzang, see Stanislas, Histoire de la Vie de Hiouen-Thsang; Beal, Si-yu-ki; Watters, On Yuan Chwang's Travels in India. On Yijing, see Chavannes, I-tsing and Takakusu, Record of the Buddhist Religion. The most thorough analysis of Faxian in European language scholarship is Deeg, 'Has Xuanzang really been in Mathurā?' and Das Gaoseng-FaxianZhuan.

3 Waley, The Real Tripitaka, 105-06 and 284, citing 'Shoku Nibonshoki, 1'. 
the Great Tang dynasty (Da Tang Da Cien si sanzang fashi zhuan 大唐大慈恩寺三藏法師傳, $Z$ no. $1192, T$ no. 2053), compiled by Huili 慧立 and Yancong 彥悰 in ten rolls, but he is not mentioned in the text. Furthermore, Dōshō is also not in the Report on the career of Trepitaka Xuanzang of the Great Tang (Da Tang gu sanzang xuanzang fashi xingzhuang 大唐故玄裝三藏法師形狀, $T$ no. 2052). Therefore, it is unclear why Waley inserted this reference to Dōshō in his otherwise erudite reading of historiographical accounts of Xuanzang's life and times. I suspect that someone told him the connection to Dōshō is a fundamental part of Xuanzang's legacy in East Asia.

There is ample evidence from both premodern East Asian sources and contemporary academic scholarship to demonstrate that Faxian and Xuanzang are the two most famous eminent Chinese Buddhist translators and pilgrims who traveled to India and numerous other kingdoms along the way, with Yijing following closely behind. Why, then, do we hear so much more about the legacy of Xuanzang than we do about Faxian? This question is as much about methodology as it is about the sources we use to reconstruct various historical trajectories or legacies in the history of East Asian Buddhism. Today, if we wish to investigate the textual legacy of Faxian, Xuanzang, or Yijing, we typically peruse printed editions of texts either in the modern Sino-Japanese Buddhist canon compiled during the Taishō era (1924-1935) in Japan, primarily following the second Korean Buddhist canon (comp. 1236-1251), or perhaps the [Zhaocheng 趙 成] Jin dynasty canon 金藏 (1147-1173), Jiaxing canon 嘉興大藏 經 (comp. 1579-1677), or the [Qianlong emperor (r. 1735-1796)] Dragon canon 龍藏 (comp. 1733-1738). ${ }^{4}$ Yet, as Sam van Schaik succinctly pointed out about Tibetan manuscripts from the so-called 'library cave' in Dunhuang, 'In the study of Tibetan Buddhism we have a canon, the $b K a$ ' 'gyur and bs Tan 'gyur, containing over a hundred volumes of scriptures, commentaries, and treatises; yet a canon

4 The most exhaustive study of Chinese Buddhist canons in English I am aware of is still Deleanu, 'Transmission of Xuanzang's Translation'; see also Wu, 'From the "Cult of the Book"'. On the Korean canon(s), see Buswell, 'Sugi's Collation Notes', 57. 
does not tell us very much about the day-to-day practice of a religious tradition'. ${ }^{5}$ It stands to reason, therefore, that if we wish to assess when, where, why-or if-Chinese pilgrims like Faxian, Xuanzang, or Yijing were as highly praised as Tucci, and others, have imagined they were in premodern East-and perhaps central—Asia, we ought to investigate manuscripts, rather than printed editions of Buddhist texts. Material evidence, including manuscripts, can speak to at least some of the motivations, lives, habits, and even routines that may have involved veneration of eminent Chinese pilgrim-translators. Manuscripts, rather than printed books or canons, serve this purpose because, 'they were not carefully selected and organized to present an idealized image of a tradition', and '[w] hen we study manuscripts we are faced with the material evidence of a social group' ${ }^{6}$

Whereas the cache of manuscripts discovered in cave seventeen of the Mogao grottoes near Dunhuang early last century are remarkable because they reflect a multilingual (e.g., in literary Chinese, Tibetan, Khotanese, Sanskrit, Old Uyghur, Tangut, Sogdian, and even Hebrew), multicultural, and even multireligious community, both the state of their preservation and organization pose problems for historical, philological, codicological, and paleographical research. Nearly 40,000 manuscripts and fragments from Chinese central Asia are now in libraries across the world: the British Museum has approximately 7,000 manuscripts with 6,000 fragments; the Bibliothèque nationale de France has about 10,000 documents; and the Institute of Oriental Manuscripts in St. Petersburg has 660 manuscript copies of Chinese Buddhist texts. ${ }^{7}$ As valuable as these manuscripts are from multiple research perspectives and questions, we probably cannot ever learn as much from them about a single social group as we can from at least two of the eight manuscript Buddhist canons preserved in Japan at Nanatsudera 七寺 (Nagoya) and Matsuo [Shintō] shrine 松尾社 (Kyoto), both of which were primarily copied during the twelfth century, chiefly from eighth century manuscripts.

\footnotetext{
5 Van Schaik, 'Uses of Implements are Different', 221-22.

6 Van Schaik, 221-22.

7 http://idp.bl.uk/pages/collections.a4d, accessed February, 2019.
} 
Because these manuscript canons have only received conscientious scholarly analysis almost entirely in Japan since the 1990s, it is unclear to me, for example, if Dōshō brought any of the manuscripts with him when he returned to Japan after studying several treatises that Xuanzang translated (e.g., Yogācāryabbūmi-sástra [Yuqiashidi lun, Yugashijiron 瑜伽師地論, $Z$ no. 690, T no. 1579] in one hundred rolls or Vijñaptimātratāsiddhi-sástra [Chengweishi lun, Joyuishikiron 成唯識論, $Z$ no. $734, T$ no. 1585] in ten rolls). It is evident that the twelfth century manuscript copies of eighth century copies of Tang dynasty (618-907) editions of Chinese Buddhist literature now preserved in Japan is that they are much more carefully organized than the incomplete Buddhist canon in the library of the small Three Realms temple (Sanjie si 三界寺) during the tenth century in cave 17 in Dunhuang. Many colophons exist to tell us about the history of these books in medieval Japan. ${ }^{8}$ The most pertinent information about the transmission of the texts that extoll the three pilgrims who traveled to India in search of the dharma and translated sacred Sanskrit scriptures into Chinese (Trepițaka, sanzang 三藏), Faxian, Xuanzang, and Yijing, is that the section of the canon devoted to eminent pilgrims ( $g u b \bar{o}$ kōsōto 求法高僧等) should contain the biography of Xuanzang ( $Z$ no. 1192, T no. 2053), Yijing's account of forty-nine Chinese and seven Korean pilgrims who journeyed to India in Biographies of Eminent Monks who Searched for the Dharma in the Western Regions (Da Tang Xiyu qiufa gaoseng zhuan 大唐西 域求法高僧傳, $Z$ no. 1193, $T$ no. 2066) in two rolls, and Faxian's autobiography, however, is incomplete in the Shōgozō collection and in the Matsuo shrine canon. Neither have the biography of Xuanzang and old Japanese manuscript canons do not preserve Report on the career of Trepitaka Xuanzang of the Great Tang (T no. 2052). ${ }^{9}$

8 See Rong, 'Dunhuang Library Cave', who highlights the role of a monk named Daozhen 道真 who seems to have supplemented the cache/canon with apocryphal sūtras, Chan texts, and other material expunged from the canon by the Chinese state during the eighth century.

9 Forte, 'Relativity of the Concept of Orthodoxy in Chinese Buddhism', 247-48, note 7. Nakao and Honmon Hokkeshū Daihonzan Myōrenji, eds., 
Curiously, neither the Shōgozō repository for Buddhist scriptures, located at Tōdaiji 東大寺 (in Nara) next to the imperial Shōsōin 正 倉院 treasury house, nor the Matsuo shrine canon appear to have kept a copy of Record of a Journey to the Western Regions (Da Tang Xiyu ji 大唐西域記, $Z$ no. 1178, $T$ no. 2087) in ten rolls, which is the account of Xuanzang's travels that Bianji 讋機 is credited with writing for him when he returned from India in $645 .{ }^{10}$ Most of the other manuscript canons that were copied on behalf of Shingon 真 言宗 temples kept copies of this famous chronicle, which, in turn, almost certainly inspired the marvelously popular adventures of Tripițaka (Xuanzang), Monkey 孫悟空, Sandy 沙悟淨, Pigsy 豬八戒, and their patron-saint, the female bodhisattva Guanyin (Avalokiteśvara) on their legendary journey from China to India in search of Buddhist scriptures in Wu Cheng'en's 吳承恩 (1501-1582) Journey to the West (Xiyou ji 西遊記). ${ }^{11}$ Another unanticipated lacunae concerns Yijing's own account of his pilgrimage to Sumatra and India, Tales of Returning from the South Seas with the Dharma (Da Tang Nanhai jigui neifazhuan 大唐南海寄歸內法傳, $Z$ no. 1204, $T$ no.

'Matsuosha issaiky $\vec{o}^{\prime}, 370-71$ : book cases (chitsu 帙) 496 and 498. On Yijing's Da Tang Xiyu qiufa gaoseng zhuan, see Buswell and Lopez, Princeton Dictionary of Buddhism, 224.

Da Tang gu sanzang xuanzang fashi xingzhuang in the Taishö canon was kept in the sutra library of Chion'in 知恩院 in Kyoto, and appears to date from the Heian period, which means it could have been [widely] available when the canons under review here were being copied; cf. $T$ no. 2052, 50: 214a3n1: 【原】 平安時代寫觀智院藏本、【甲】平安時代寫寶菩提院本.

10 On the Shōgozō, see Lowe, 'The Discipline of Writing'; 'Buddhist Manuscript Cultures in Premodern Japan'.

11 The end of the road for these pilgrims is an encounter with the Buddha, who, coincidentally, resides in Thunderclap Monastery 大雷音寺 on Vulture peak 靈山 (Gṛdhrakūța-parvata). He arranges for them to receive precisely 'one canon' (yizang 一藏)—or 'treasury'—of Buddhist scriptures, which amounts to precisely 5,048 rolls or scrolls 卷; see the translation by Wu Cheng'en and $\mathrm{Yu}$, Journey to the West, Revised Edition, Volume 4, 396, n.7. Da Tang Xiyu ji is only absent from the Shōgozō and Matsuo shrine MSS canons in Japan. 
2125), which is preserved at Matsuo shrine and Nanatsudera, but not in the Shōgozō. ${ }^{12}$

MSS Editions of Faxian's Works: Dunhuang, Nanatsudera and the Matsuo Shrine Canons

Because of ground breaking efforts by members of the Academic Frontier Project of the International College for Postgraduate Buddhist Studies 国際仏教学大学院大学学術フロンティア実行 委員会 (ICPBS) in Tokyo, directed by Ochiai Toshinori 落合俊 典, we know a great deal about the Nanatsudera and Kongōji 金剛 寺 canons. Rediscovered in 1990 by a team of researchers in Japan that included Ochiai and Antonino Forte, which was already catalogued in 1968 by a team from the Agency for Cultural Affairs 文 化庁, the Nanatsudera collection of scriptures is remarkable because it is clearly organized according to the Newly Revised Catalog of Buddhist Scriptures, Compiled During the Zhenyuan Era [785-805] (Zhenyuan xinding Shijiao lu 貞元新定釋教録, $Z$ no. 1184, $T$ no. 2157, comp. 800), rather than what we presume all fifteen premodern printed Chinese Buddhist canons-from the Kaibao ed. 開寶藏 (971-983) to the Dragon Canon-loosely follow: the order outlined in Record of Śakyamuni's Teachings, Compiled During the Kaiyuan Era [713-741] (Kaiyuan Shijiao lu 開元釋教錄, $Z$ no. 1183, $T$ no. 2154, comp. 730). Yet the Nanatsudera canon has more texts than it should. Instead of 1,258 titles in 5,390 rolls as the Taisho edition contains, the Nanatsudera edition of the Zhenyuan lu has 1,206 titles in 5,351 rolls. The Nanatsudera edition of the Kaiyuan lu, which is copied from a manuscript dated to 735 (Tenpyō 天平 7) and brought back to Japan by Genbō 玄昉 (d. 746; in China: 718-735), has 1,046 titles in 5,048 rolls, in contrast to the Taisho edition with 1,076 titles

12 The Shōgozō contains 715 titles in 4,063 scrolls, which were hand-copied at the behest of the imperial family during the Nara period eighth century. Cf. Iida, 'Shōgōzō kyōkan "Jingo keiun ni nen gogangyō” ni tsuite'; Sakaehara, Shōōōin monjo nyūmon. 
in the same number of rolls. The Matsuo shrine canon closely reflects the Nanatsudera Zhenyuan lu, but only 3,545 rolls are extant. ${ }^{13}$

The Matsuo shrine canon may only appear to be incomplete. Whereas the Nanatsudera canon has 4,954 rolls and the Kongojji canon has about 4,500, despite the ravages of time, only 3,545 rolls (approx. 825 separate titles) of the Matsuo shrine canon survive today. Nevertheless, this canon is remarkable because of the number of colophons (okugaki 奥書) it has. The Nanatsudera canon has 378 rolls with colophons (158 separate titles) with dates or marginalia; the Kongōji canon has about 230 rolls (103 titles) with colophons. The Matsuo shrine canon has 1,236 rolls (approx. 345 titles) with colophons that provide dates, collation information, scribes' names, and evidence to tell us why both Shintō priests (kannushi $i$ 神主, negi 襧宜, etc.) and Buddhist monastics copied scriptures at sacred sites across the Kinki 近畿 region and beyond to be recited before the

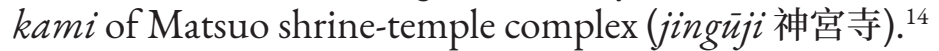

In the following analysis of texts about, connected to, or attributed to Faxian preserved in East Asian canons, I compare manuscripts primarily from the Matsuo and Nanatsudera canons in Japan to those from Dunhuang and what is now held in the Institute of Oriental Manuscripts St. Petersburg from other archaeological excavations by Pyotr Kozlov who made an expedition to Khara-Khoto (Heishuicheng 黑水城) during 1907-1909. ${ }^{15}$

There are six texts connected to Faxian: (a) Biography of the Eminent Monk Faxian (Gaoseng Faxian zhuan, $Z$ no. 1194, $T$ no. 2085, 51: 857a2-866c6), also known as Record of Buddhist Kingdoms (Foguo ji) in one roll; (b) Mahāyāna Mahāparinirvānā-sūtra (Da bannibuan jing 大般泥洹經, $Z$ no. 137, $T$ no. 376, 12: 853a2-899c24) in six rolls; (c) the so-called non-Mahāyāna Mabāparinirvānā-sūtra (Da banniepan jing 大般涅槃經, $Z$ no. 774, T no. 7, 1: 191b2-207c12) in three rolls; (d) Kșudraka-sütra (Foshuo zazang jing 仏説雑藏経, $Z$ no. $884, T$ no. 745,17 : 557b11-560b6)

\footnotetext{
13 Keyworth, 'Apocryphal Chinese books', 3, 8.

14 Keyworth, 2.

15 Solonin, 'Glimpses of Tangut Buddhism'.
} 
in one roll; (e) *Mahāsāmghika-vinaya (Mohe sengqi lü 摩訶僧祇 律, $Z$ no. 1008 , $T$ no. 1425 , 22: 227a2-549a3) in forty rolls; and (f) *Mahāsāmghika-bbikṣuñi-prätimokșa-sūtra (Mohe sengqi biqiuni jieben 摩訶僧祇比丘尼戒本, $Z$ no. 1017, $T$ no. 1427, 22: 556a22-566c6).

No copy of the Biography of the Eminent Monk Faxian was discovered in cave seventeen at Dunhuang. ${ }^{16}$ Only a small fragment of the Mahāyāna Mahāpariniruāna-sūtra ( $Z$ no. $137, T$ no. 376) survived from Chinese central Asia. It is in the St. Petersburg collection, Dx3203 corresponds with Daban nibuan jing 2, T no. 376, 12: $867 c 4-14 .{ }^{17}$ There are ten fragments of the non-Mahāyāna version of the Mahäparinirvāna-sütra ( $Z$ no. $774, T$ no. 7 ) from Dunhuang. ${ }^{18}$ Two fragments of the Ksudraka-sütra are extant: P. 3710 [T no. 745, 17: 557b14-c15] and F142 [T no. 745, 17: 557c15-558c4]. There are nearly sixty fragments of the * Mahāsāmghika-vinaya from the Stein, Pelliot, St. Petersburg, and Chinese collections. ${ }^{19}$ Finally,

16 Kokusai bukkyōgaku daigakuindaigaku fuzokutoshokan, Taishōzō Tonkō, 228.

17 Kokusai bukkyōgaku daigakuindaigaku fuzokutoshokan, 130.

18 Kokusai bukkyōgaku daigakuindaigaku fuzokutoshokan, 3: BD6207-2 [T no. 7, 1: 411a7-419c29] and S. nos. 486 [ $T$ no. 7, 1: 411a16-c3], 6072 [ $T$ no. 7, 1: 4428b16-28], 81 [T no. 7, 1: 429a10-433c19], 3385 [ $T$ no. 7, 1: 441a14446b15], 489 [ $T$ no. 7, 1: 482b9], 6534 [ $T$ no. 7, 1: 522b2-528a4], 307 [ $T$ no. 7, 1: 522b18-528a4], 2849 [T no. 7, 1: 543c29-546b6], and 2855 [T no. 7, 1: $574 \mathrm{~b} 10-580 \mathrm{c} 16]$.

19 Kokusai bukkyōgaku daigakuindaigaku fuzokutoshokan, 212-13. T no. 1425, 22: 227a2-549a3 viz. S. 5766[14] (T no. 1425, 22: 235a2-9), S. 5766[15] ( $T$ no. 1425, 22: 235b10-c24), S. 3448 ( $T$ no. 1425 , 22: 235c14236a7), S. 5766[2] ( $T$ no. 1425, 22: 235c24-236a11), S. 5766[3] ( $T$ no. 1425, 22: 236a28-b11), S. 5766[7] ( $T$ no. 1425, 22: 236b14-29), S. 5766[9] ( $T$ no. 1425, 22: 236c6-10), S. 5665[2-3] (T no. 1425, 22: 239b26-c22), S. 5665[22] ( $T$ no. $1425,22: 239 c 24-243 a 2), S .5665[2-5]$ ( $T$ no. $1425,22: 240 \mathrm{a} 7-21)$, S .5665[2-13] ( $T$ no. 1425, 22: 240a24-c4), S. 5665[2-1] ( $T$ no. 1425, 22: 240c4-241a4), S. 5665[2-14] ( $T$ no. 1425, 22: 241a4-16), S. 5665[2-8] ( $T$ no. 1425, 22: 243a5-28), S. 5665[2-9] (T no. 1425, 22: 243b3-c5), S. 5665[2-10] ( $T$ no. $1425,22: 243$ c9-244a12), S. 5665[2-11] ( $T$ no. 1425, 22: 244a12-b15), 
there are three fragments of the ${ }^{*}$ Mahāsāmghika-bbiksunī-prātimoksa-sūtra. ${ }^{20}$

Although there are no colophons to rolls 2280-2282 of the Matsuo shrine canon, these comprise the three chapters of Faxian's translation of the non-Mahāyāna Mahäparinirvāna-sūtra. ${ }^{21}$ Also without colophons, rolls 3417-3419 are together in a designated section for biographies of three Chinese eminent monks who searched

Dx197 ( $T$ no. $1425,22:$ 244c22-245b2), Dx199 ( $T$ no. 1425, 22: 245b2-c6), Dx198 ( $T$ no. 1425, 22: 245c7-19), S. 5665[2-7] ( $T$ no. 1425, 22: 248a28b26), S. 5665[2-6] ( $T$ no. 1425, 22: 248b29-c29), S. 5665[2-12] ( $T$ no. 1425 , 22: 249a7-16), S. 5665[2-4] ( $T$ no. 1425, 22: 249b5-b19), S. 5665[2-15] ( $T$ no. 1425, 22: 249b21-c7), S. 5766[5] (T no. 1425, 22: 250c2-15), S. 5766[4] (T no. 1425, 22: 250c18-251a2), S. 5766[12] (T no. 1425, 22: 251a5-18), S. 5766[13] ( $T$ no. 1425, 22: 251a18-b5), S. 5766[10] ( $T$ no. 1425 , 22: 251b7-19), P. tib. 1073V ( $T$ no. 1425, 22: 262a17-b16), BD5274 (T no. 1425, 22: 264a17-c15), BD11562 ( $T$ no. 1425, 22: 264c11-c19), BD10137 ( $T$ no. $1425,22: 264 \mathrm{c} 19-$ 26), BD11752 ( $T$ no. $1425,22: 265$ b18-c9), BD10386 (T no. $1425,22: 265$ c2223), BD9854 ( $T$ no. $1425,22: 265$ c24-266a7), Zhejiang no.136 ( $T$ no. 1425,22 : 266a6-19), Zhejiang-no.137 ( $T$ no. 1425, 22: 266a19-b1), BD2481 ( $T$ no. 1425 , 22: 266b21-c19), BD7649 ( $T$ no. 1425, 22: 266c19-267a26), BD10859 ( $T$ no. 1425, 22: 267a26-b1), BD12035 (T no. 1425, 22: 267b9-16), BD9687 ( $T$ no. 1425, 22: 267b26-c11), BD10439 (T no. 1425, 22: 268a8-12), Zhejiang no.66 ( $T$ no. 1425, 22: 268a12-27), P. 3996 ( $T$ no. 1425, 22: 268a26-b15), BD11120 ( $T$ no. 1425, 22: 268b14-20), Dx2602A2 ( $T$ no. $1425,22: 268 c 25-269 \mathrm{a} 7)$, Dx2602A1 ( $T$ no. $1425,22: 269 \mathrm{a} 8-29)$ ), BD3068 ( $T$ no. 1425, 22: 269b28270c24), Dx3938 ( $T$ no. 1425, 22: 282c8-283a17), Dx5484 (T no. 1425, 22: 283a17-b29), BD1345V3 (T no. 1425, 22: 285b2-286a21), Guohui-no.32(47)-2 ( $T$ no. 1425, 22: 304a19-306b16), S. 2818 (T no. 1425, 22: 320b24-324b24), Dx2728[1] ( $T$ no. 1425, 22: 335a8-b10), Dx2728[2] ( $T$ no. 1425, 22: 360a816), Dx2728[3] ( $T$ no. 1425, 22: 369b15-23), Dx5214 (T no. 1425, 22: 378b29c23), BD14569 (T no. 1425, 22: 452a5-460a29).

20 Kokusai bukkyōgaku daigakuindaigaku fuzokutoshokan, 106: BD10695 [ $T$ no. 1427, 22: 556b20-28], BD14930 [ $T$ no. 1427, 22: 556a21-565a20], and BD11486 [T no. 1427, 22: 556b28-c8].

21 Nakao and Myōrenji, eds., 'Matsuosha issaikyō, 426-29. 
for the Dharma (guhō kōsōtō): Yijing's Biographies of Eminent Monks who Searched for the Dharma in the Western Regions ( $Z$ no. 1193, $T$ no. 2066, rolls 3417-3418) comes first, followed by Faxian zhuan (3419)..$^{22}$

Rolls 1176-1181 of the Matsuo shrine canon provide much more information about when and where these manuscripts were copied. What seems incongruous is that the first three rolls (1176-1178) of Faxian's Mahāyāna Mahāparinirvāna-sūtra were copied from an original manuscript, which was probably in a private library that belonged to the abbot of a small cloister (Tōrinbō 東林房) at Higashidani in Saitōin of Enryakuji 延暦寺西塔院東谷 on Mount Hiei 比㪍山. There is no copy date, but Gonkaku 厳覚 (1056-1121) checked this edition when he either copied these rolls for Matsuo shrine or for his own monastic library at Miidera 三井寺 (alt. Onjōji 園城寺). Since $1115.6 .1^{23}$ is the earliest date we have for colophons on other rolls in the Matsuo shrine canon, it appears that this is the right Miidera monastic that could have copied Faxian's translation of the Mahāyāna Mahāparinirvāna-sūtra to vow to the kami of Matsuo shrine. However it is curious why Gonkaku would have copied a manuscript on behalf of Matsuo shrine from an assumed scriptorium up on Mount Hiei, where warrior monks (sōhei 僧兵) literally beat or killed their Tendai rivals. ${ }^{24}$ Sōjun 相順 (alt. Shōjun), who may have been another Miidera monastic or perhaps an Enryakuji monk, copied rolls four to six (1179-1181) of the Mahāyāna Mahāparinirvāna-sūtra from an original [once] held by Seiryūji 青竜寺 at KitaKurodani 北黒谷 in Saitōin of Enryakuji on Mount Hiei 比㪍山. ${ }^{25}$

\footnotetext{
22 Nakao and Myōrenji, eds., 'Matsuosha issaikyō', 370.

23 All dates in this format are to the Lunisolar calendar and not the Gregorian calendar.

24 Gonkaku, in Nihon jinmei daijiten. It appears that Gonkaku was a prominent disciple of Gyōson 行尊 (1055-1135), a famous exegete and esoteric Buddhist ritual master from Miidera. On Miidera-Enryakuji struggles, see, Adolphson, Teeth and Claws of the Buddha, and Keyworth, 'Apocryphal Chinese books', 16-17 and Appendix 1.

25 Nakao and Myōrenji, eds., 'Matsuosha issaikyö', 238 with notes 395-400.
} 
The other three primary translations attributed to Faxian include the Ksudraka-sütra (Foshuo zazang jing 仏説雑藏経, $Z$ no. 884, $T$ no. 745 ); 'Mahāsāmghika-vinaya (Mohe sengqi lü 摩訶僧祇律, $Z$ no. $1008, T$ no. 1425$)$ in forty rolls; and ${ }^{*}$ Mahāsāmghika-bbikșuniprātimokșa-sūtra (Mohe sengqi biqiuni jieben 摩訶僧祇比丘尼戒本, $Z$ no. 1017, $T$ no. 1427). Roll 2363 in the Matsuo shrine canon is the Kșudraka-sūtra, rolls 2565-2599 are the Mabāsāmghika-vinaya, and roll 2714 is the Mahāsāmghika-bbiksunī-prātimokșa-sūtra. ${ }^{26}$ There are no colophons for any of these rolls. Perhaps this is not unforeseen either because these scriptures belonged to a shrine-temple complex where we cannot presume that strict adherence to the [Indian] monastic codes was especially relevant to married shrine priests or their aristocratic kin, or because the bulk of the Matsuo shrine canon seems to have been copied by and from Tendai libraries affiliated with either Miidera and the Tendai Jimon 寺門派 (Temple) or Mountain (Sanmon-ha 山門派) branch up on Mount Hiei within the massive monastic complex of Enryakuji.

\section{Nara versus Tendai: exegetes versus pilgrims-ritual masters}

According to traditional Japanese narratives about Heian-era (794-1185) religion, politics, and institutional history, after Kūkai 空海 (774-835) and Saichō 最澄 (767-822) returned from pilgrimages to China in search of the dharma in the early ninth century, the religious context for Buddhism in the archipelago was altered forevermore. Even though we now know that it was their disciples who followed in their footsteps-and revered Chinese pilgrims to India - and ventured to the continent in search of sacred Buddhist texts and ritual manuals to find a corpus of highly unified esoteric or tantric texts and rituals translated under the direction of three translators, Subhakarasiṃha 善無畏 (in China 719-735),

26 The Matsuo shrine canon has rolls 2-6 (2565-2569), 8-20 (2570-2582), 22-29 (2583-2590), 31-37 (2591-2597), and 39-40 (2598-2599) of the Mahāsāmghika-vinaya. 
Vajrabodhi 金剛智 (662-732), and Amoghavajra [Jin'gang 金剛] Bukong 不空 (705-774), rather than either Kūkai or Saichō, who actually introduced esoteric Buddhism to Japan, there seems to be little question that the institutions of Tōji 東寺 (formally Kyōōgokuji 教護国寺), Enryakuji, and Miidera rivaled the older, seven great state-sponsored temples in Nara. ${ }^{27}$ In addition to manuscript-and printed-editions of Buddhist scriptures and commentaries held primarily by Nara temples and monasteries, pilgrims brought new editions and texts to Shingon, Tendai, and new imperially- and aristocratic family-sponsored temples and shrine-temple complexes during the ninth to twelfth centuries. On the one hand, we have the Shōgozō, which primarily preserves texts presumably significant for Buddhists in Nara, with special consideration for the communities from Tōdaiji and Kōfukuji 興福寺, as well as other Kegon- 華厳 宗 and Hossō- 法相宗 affiliated temples such as Hōryūji 法隆寺 and Kiyomizudera 清水寺 (in Kyoto). On the other hand, we have ample evidence that suggests there was a primarily Tendai sponsored canon-or set of canons-which was copied from a vowed canon held at emperor Shirakawa's 白河 (1053-1129, r. 1073-1087) Hosshōji 法勝寺. Fujiwara no Tadahira 藤原忠平 (880-949) had Hosshōji converted into a temple in 925 . Shirakawa unofficially ruled-rather than reigned-from this cloister after 1077.

Among the many rare books in the Shōgozō is a tenth century printed edition for Kasuga shrine (春日版) of Xuanzang's Vijñaptimātratāsiddhi-sástra ( $Z$ no. 734, $T$ no. 1585) from Kōfukuji, as well as sufficient evidence about the first canon vowed (ganmon 願文) and copied in 740 under the patronage of Queen Consort Kōmyō 光明 (701-760)—the 5/1 canon (Gogatsuichinichikyō 五 月一日経)—that had 4,243 rolls. $^{28}$ There appears to be scholarly

27 Strickmann and Faure, Chinese Magical Medicine, 206-07. The great seven Nara temples include: Kōfukuji 興福寺, Tōdaiji 東大寺, Saidaiji 西大寺, Yakushiji 薬師寺, Hōryūji 法隆寺, Gangōji 元興寺, and Daianji 大安寺 or Tōshōdaiji 唐招提寺 or even Hokkeji 法華寺.

28 Nara National Museum, ed., Special Exhibit, 54-56, English explanations 166. Dated colophons are from 1088, 1116, and 1119. 
consensus that this canon was, in turn, widely distributed in Japan among aristocrats, and especially by the Fujiwara family, which sponsored Kōfukuji and nearly all other Hossō temples-including Kiyomizudera - as well as Kimpusenji 金峯山寺, a Fujiwara temple affiliated with the mountain training monk tradition called shugendo 修験道. ${ }^{29}$ Coupled with the manuscripts copied, at least in part, from Hosshōji, scholars are roughly divided between two explanations for the existence of these canons. Abe Yasurō has written extensively on the notion of ritual offerings (kuyō 供養, pujjā ) of either Xuanzang's massive translation of the Great Perfection of Wisdom Sütra or sets of 'all the scriptures' as part and parcel of ritual activities increasingly bolstered by an esoteric Buddhist orientation toward conferring merit on or placating all manner of autochthonous and allochthonous deities. ${ }^{30}$ Colophons from the Nanatsudera and Matsuo shrine scriptures establish that they were intended to be read or chanted in front of or for the kami (shinzen dokyo 神前読経) to alleviate natural and man-made disasters and to bolster the imperial and aristocratic clans. ${ }^{31}$

Another approach to these manuscripts is to assess their likely use by exegetes from Nara-especially Hossō monastics—and Shingon

The 5/1 canon took twelve years to complete; we have approximately 3,500 rolls from it today in the Shōgozō collection: Abe, Chūsei Nihon no shūkyō tekusuto taikei, 156. Abe suggests that it must have been this canon which was recited-in part or in full-at the consecration of the state of Vairocana buddha in Tōdaiji in 752.

29 Chüsei Nihon no shükyō tekusuto taikei, 176-77; and Nara National Museum, Special Exhibit of Ancient Sutras from the Heian Period, nos. 15-17, 168, which show that the Fujiwara clan sponsored preserving scriptures-especially the Lotus Sütra (Saddharmapundarika-sūtra, Fabua, Hokkekyō 法華経, $Z$ nos. 146-149, T nos. 262-264) -in so-called sūtra mounds (kyōzuka 経塚 or maikyō 埋経) in preparation for mappō 末法 in 1052.

30 Abe, Chüsei Nihon no shükyō tekusuto taikei, 286-335.

31 Nara National Museum, Special Exhibit, images nos. 14-1 and 14-2 on pages 32-41, have the same colophon discussed in Keyworth, 'Apocryphal Chinese books', 2, to the Great Perfection of Wisdom Sütra. 
and Tendai temples who participated in court-sponsored debates. ${ }^{32}$ While it may seem intriguing to ponder the idea of shrine-temple religious professionals or priests studying arcane treatises such as the Chengshi lun 成實論 (Tattvasiddhi-śástra?, $Z$ no. 1086, T no. 1646]) or Xuanzang's translations of the Vijñaptimātratāsiddbi-śastra or * Abhidharmanyāyānusāra-śāstra [Saṃghabhadra] (Apidamo shunzheng lun 阿毘達磨順正理論, $Z$ no. 1076, T no. 1562), contextual evidence seems to support Abe's perspective about the Nanatsudera and Matsuo shrine scriptures. There is, however, an important caveat: Sangō and Minowa's research clearly demonstrates that Miidera monastics during the twelfth century were particularly successful at these debates, which suggests that the colophons from Faxian's Mahāyāna Mahāparinirvāna-sūtra in the Matsuo shrine scriptures may provide evidence of Jimon branch Tendai-orientated views of what was important within an issaikyō.

On pilgrims who traveled to China in search of sacred scriptures (guhō kōsō)

The sectarian world of Heian-era Japanese religion cannot, however, be mapped on to any advantageous or constructive impression of continental Buddhism, even when it comes to the matter of the reception of Chinese pilgrim-monks and translators in Japan. According to Gyōnen Daitoku 凝然大德 (1240-1321) in the Hasshu $k \overline{o y o}$ 八宗綱要 (Guiding Essentials of the Eight Sects, comp. 1268), there are eight 'schools' (shü) of Japanese Buddhism: (1) Kusha 俱舍 (Abhidharma); (2) Jōjitsu 成實 (Tattvasiddhi-śāstra, $Z$ no. 1086, T no. 1646]); (3) Ritsu 律 (Vinaya); (4) Hossō (Yogācāra); (5) Sanron 三論 (Madhyamaka; Three Treatises); (6) Tendai; (7) Kegon (Buddhāvatamsaka-sütra, $Z$ nos. 95-96, $T$ nos. 278-279); and (8) Shingon. ${ }^{33}$ Missing, of course, are the so-called 'New Buddhism’ Pure Land traditions and Zen 禅宗. Often referred to by

32 Minowa and Groner, 'The Tendai Debates'; Sango, The Halo of Golden Light and 'Buddhist Debate'. 
scholars as the Southern Capital schools (Nantō bukkyō 南東仏教), these sects of Japanese Buddhism are different from Tendai, Shingon, Jōdoshū 浄土宗, Jōdoshinshū 浄土真宗, and the three Zen traditions (Rinzai 臨済宗, Sōtō 曹洞宗, and Ōbaku 黄檗宗) because they cannot claim to transmit orthodox lineages, and their teachings rest upon particular commentaries (śāstras) and scriptures. ${ }^{34}$ By virtue of having been founded during the Nara period, Hossō and the other Nara schools are closely connected to the eminent, aristocratic Fujiwara family, which sponsored numerous trade and diplomatic missions to the continent during the seventh to eleventh centuries. ${ }^{35}$ It is these Nara schools that presumably prompted Stanley Weinstein to pronounce that we must err on the side of caution when speaking of separate shu or zong 宗 in the history of Chinese (or continental East Asian) Buddhism:

The root of the problem lies in the word tsung, for which dictionaries list as many as twenty-three separate definitions. In Buddhist texts, however, it is used primarily in three different senses: (1) it may indicate a specific doctrine or thesis, or a particular interpretation of a doctrine; (2) it may refer to the underlying theme, message, or teaching of a text; and (3) it may signify a religious or philosophical school...Tsung in the sense of doctrine or thesis is frequently encountered in fifth-century texts in such phrases as kai-tsung [開

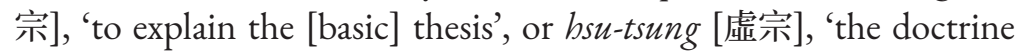
of emptiness'. Especially common was the use of the term tsung to categorize doctrinal interpretations of theses enumerated in a series... The term tsung should be translated as 'school' only when it refers to a tradition that traces its origin back to a founder, usually designated 'first patriarch', who is believed to have provided the basic spiritual

33 Bielefeldt, 'Kokan Shiren', especially 305. On the Hasshū kōyō, see Pruden, 'Hasshu koyo'. The best translation of the Hasshū kōyō is Kamata, 'Chūgoku bukkyōshi jiten'.

34 For just one example, see Sueki, Shimoda, and Horiuchi, eds., Bukkyō no jiten, 113-17.

35 Grapard, Protocol of the Gods and 'Institution, Ritual, and Ideology'. 
insights that were then transmitted through an unbroken line of successors or 'Dharma heirs'. ${ }^{36}$

Whether or not Xuanzang actually translated the seventy-seven treatises or sütras A. C. Muller culled from Louis Lancaster's catalog, The Korean Buddhist Canon, it seems to be his status as the preeminent translator-pilgrim that was buttressed in Japan in Nara at Kōfukuji via lavish patronage from the Fujiwara family. ${ }^{37}$ Until the editors of the Taisho made several rather peculiar amendments to the order of all manner of texts in the East Asian Buddhist canon, including moving the so-called Agama 阿含部 ( T nos. 1-151, vols. 1-2) and Jātaka 本緣部 ( $T$ nos. 152-219, vols. 3-4) sections from the middle to the front of the canon, Xuanzang's translation of the Great Perfection of Wisdom Sūtra (Mabāprajñāpāramitā-sūtra, Dabore boluomiduo jing, Daibannya haramittakyō 大般若波羅蜜多 經, $Z$ no. $1, T$ no. 220 ) came first. ${ }^{38}$ Perhaps because it was the first and longest Mahāyāna Buddhist scripture or because it explicitly says to do so, this scripture was widely copied and distributed for merit-making and to prevent natural disasters or subdue a wide range of Indian and East Asian deities. ${ }^{39}$ Several scholars, including Sagai Tatsuru, see the merit-making activities connected to proliferating Xuanzang's translation of the Great Perfection of Wisdom Sütra as the likely basis for large-scale coping projects of all the scriptures (issaikyo 一切経) in Nara Japan that led to the production of the

\footnotetext{
36 Weinstein, 'Chinese Buddhism', Vol. 2, 482-84.

37 http://www.acmuller.net/yogacara/thinkers/xuanzang-works.html, accessed
} March, 2019. Cf., Lancaster and Park, The Korean Buddhist Canon.

38 The most insightful and succinct account of Chinese Buddhist canons and catalogs is in Sueki Fumihiko, Shimoda Masahiro, and Horiuchi Shinji, Bukkyō no jiten, 44-46. See also the essays in Wu and Chia, eds., Spreading Buddha's Word.

39 On examples from medieval Japan, see Keyworth, 'Apocryphal Chinese books', 15. Just one example of how popular the Mahāprajñāpāramitā-sūtra in 600 rolls was elsewhere in East Asia during the premodern period can be glimpsed from the translation into Tangut: Huang, Zhongguo guojia. 
Matsuo shrine, Nanatsudera, and six other extant old Japanese canons we have access to today. ${ }^{40}$

What is clear from the intricate history Abe Yasurō, Sagai Tatsuru, and Bryan Lowe provide of the early history of copying the canon and the Great Perfection of Wisdom Sütra in eighth to tenth century Japan is that Kōfukuji played an essential role-as did Hōryūji, another Hosso affiliated, legendary temple-in the dissemination of scriptures in premodern Japan. An example discussed previously is the tenth century Kasuga [shrine] printed edition of Xuanzang's Vijñaptimātratāsiddhi-sástra from Kōfukuji which demonstrates the extent to which it appears that Xuanzang's 'lineage' or 'school' disseminated his teachings in Nara. Unlike especially the Tendai and Shingon traditions during the ninth to twelfth centuries especially, the institutions that produced our old manuscript canons, the Hossō tradition did not celebrate a lineage of patriarchs that connected them to nor necessitated a pressing need for paying close attention to the ideal of pilgrims who traveled to China in search of sacred scriptures $(g u b \bar{o} k \bar{o} s \bar{o})$. The need to construct a Hossō patriarchate would only develop centuries later. From the additional perspective of translation in Japan, there is another reason why Xuanzang stands

40 Sagai, Shinbutsu shūgō. On the history of these canons, see Abe, Chüsei Nihon no shükyō tekusuto taikei, 174-85. Lowe, 'Contingent and Contested', especially 228. Alternative evidence exists from Shiga prefecture, where Prince Nagaya 長屋王 (680-729) sponsored the Great Perfection of Wisdom Sütra between 712-728, which appear to have been copied from scriptures once held in the Fujiwara capital 藤原京 (694-710). See Iwamoto, 'Nagaya no ōkimi hotsugankyō (zō wadō kyō) denraikō'; see also Abe, above. Funayama, Butten wa dou kanyaku sareta no ka, 11-12 makes an important distinction between the East Asian Buddhist terms meaning 'all the collected scriptures' (yiqie jing, issaikyō), which he posits can be traced to the Taihe 太和 [3] reign period (ca. 479) of the Northern Wei dynasty (386-534) and in use during the Northern and Southern Dynasties period (420-589), 'collected scriptures' (zhongjing, shukyō 衆經), used more prominently in southern China from the mid-sixth century on, and 'canon' [referring to the tripitaka] (da zangjing, daizōkyō), which was applied by the Tang (618-907) government. 
alone: he initiated a 'new' system of translating Sanskrit into Chinese (shinyaku 新訳 versus kuyaku 旧訳) with phonetic changes such as sanmodi (sanmaji) 三摩地, rather than sanmei (sanmai) 三昧, for samādhi. By extension, Xuanzang inaugurated a new period in the history of Chinese Buddhist translation; whereas Faxian-with his part-time collaborator Buddhabhadra 仏駄跋陀羅 (alt. 佛陀咙陀羅, 359-429) in Jiankang 建康—exemplifies 'old' translations. It would be a gross distortion of the historical records to suggest that either Xuanzang's so-called 'new' translations were more popular than 'older' texts.

During the Nara period, many Hossō and Sanron monks made the perilous voyage to China in search of sacred scriptures-and perhaps teachers like Xuanzang. Here is a short list of some of these monks:

1. Dōji 道慈 (?-744, Sanron monk): Taihō 大宝 2.6 (702)-Yōrō 養老 2.10 (718), in China 17 years.

2. Bensei 弁正 (d.u.): Taihō 2.6 (702)-?? Poet-monk in China.

3. Genbō (?-746, Hossō monk): Yōrō 養老 1.3 (717)-Tenpyō 天平 5.4 (733), in China 18 years.

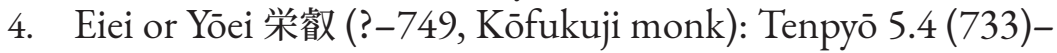
died in China; in China 16 years. Met Ganjin 鑑真 (Jianzhen, 688-763) in China.

5. Fushō 普照 (d.u., Kōfukuji monk): Tenpyō 5.4 (733)-Tenpyō shōhō 天平勝宝 6 (754), in China 21 years. Met Ganjin in China after 10 years.

6. Genrō 玄郎 (d.u., Kōfukuji monk): Tenpyō 5.4 (733)Tenpyō 14 (742/743) returned to Japan.

7. Genhō 玄法 (d.u., Kōfukuji monk): Tenpyō 5.4 (733)Tenpyō 14 (742/743) returned to Japan.

It would appear that not long after the capital was moved to Kyoto, in 794, however, we see another category of pilgrims who traveled to China in search of sacred scriptures. These ten are the most famous, and have everything to do with why we saw that the texts that celebrate Xuanzang do not seem to have been as admired at Matsuo or Nanatsudera as the texts which commemorate either Faxian or Yijing. 
1. Saichō (767-822): Enryaku 延暦 23.7 (804.7)-Daidō 大同 1.6 (805.6). Traveled to Tiantaishan 天台山; in China 1 year.

2. Kūkai (774-835): Enryaku 23.7 (804.7)-Daidō 1.10 (806.10). Traveled to Chang'an, in China 2 years.

3. Ennin 圓仁 (794-864): Jōwa 承和 5 (838.6.17)-Jōwa 14 (847.9.18). Traveled to Tiantaishan and Wutaishan 五臺山; in China 9 years and 4 months. ${ }^{41}$

4. Enchin 圓珍 (814-891): Ninju 仁寿 3 (853.7.15)-Tennan 天 安 1 (858.6.22). In China 4 years and 4 months.

5. Shūei 宗頻 (809-884, Shingon monk): Jōgan 貞観 4 (862)Jōgan 7 (865). Traveled to Wutaishan and Bianzhou 泫州.

6. Chōnen 䢛然 (938-1016, Shingon monk): Eikan 永観 1 (983)-Kanna 寛和 2 (986). Traveled to Tiantaishan, Wutaishan, and the Song capital of Bianjing 泣京. Raised funds for restoration of Tōdaiji. See Nittōki 入唐記.

7. Nichien 日延 (d.u., Tendai 天台宗 monk): Tenryaku 天暦 7 (953)-Tentoku 天徳 1 (957). Visited Wuyue Kingdom 吳越國 (907-978) under Qian Chu 錢俶 (r. 947-978); witnessed dissemination of Baoqieyin ta 寶筮印塔 stūpas (J. Hōkyōinntō, Sarvatathāgatadhiș̣thāna-hṛdayaguhyadhātu karandamudrā-dhārañī, T nos. 1022a, 2023) .

8. Jakushō 寂照 (962-1034, Tendai monk): Chōtoku 長徳 5 (1003)-died in China. Secular name Ōe no Sadamoto 大江定 基. See Raitōn nikki 来唐日記.

9. Jōjin 成尋 (1011-1081): Enkyū 延久 4 (1072)-died in China. See San Tendai Godai san ki 參天臺五臺山記.

10. Kaikaku 戒覚 (d.u., Tendai monk): (1082)-??. On Yuanfeng 5 (1082) 9.18 at Wutaishan. ${ }^{42}$

The narrative of what Kūkai may-or may not-have personally acquired in terms of texts, teachings, and ritual technology is well beyond the scope of this study. ${ }^{43}$ Almost all the other pilgrims

\footnotetext{
41 Cf. Nittō gubōjunrei gyōki 入唐求法巡礼行記.

42 See Tosōki 渡宋記.

43 See Abé, The Weaving of Mantra; 'Scholasticism, Exegesis, and Ritual Practice'.
} 
speak to the tradition(s) of Buddhism best represented by the contents of the Matsuo shrine canon and, by extension, the Nanatsudera canon as well.

There are two Tendai lineages that trace back to two pilgrims: Ennin and Enchin. Ennin's diary, Record of a Pilgrimage to Tang China in Search of the Dharma (Nittō guhō junrei gyōki 入唐求法 巡礼行記), became a guide for later pilgrims, including Jōjin, whose diary may be even more valuable for the study of Buddhism in China than Ennin's. ${ }^{44}$ Enchin's (Chishō daishi 智証大師), diary, of sorts, is Gyorekisho 行歴抄. ${ }^{45}$ Both are, therefore, examples of pilgrims who ventured to the continent in search of the Dharma, and returned to Japan to establish-through their immediate disciples-distinctive lineages of East Asian Buddhism. When a dispute arose over the selection of Enchin as the fifth chief abbot (zasu 座主) of Enryakuji in 873, Ennin's followers protested, and subsequently Enchin and his supporters fled down the mountain to Miidera, where they established the Tendai Jimon 寺門派 (Temple). ${ }^{46}$ Ennin's followers established the Mountain (Sanmon-ha 山門派) branch of the Tendai tradition of Japanese Buddhism, which led to centuries of strife between these two armed factions.

Perhaps because of this monastic violence, the Tendai tradition is severely underrepresented in contemporary research on Japanese religion both in Japan and beyond. Even though we have a comparatively clear picture of the institutional history of Nara Buddhist schools and of the Shingon tradition during the medieval period, the Matsuo and Nanatsudera canons suggest that without greater attention to the textual history of the Tendai traditions we might continue to possess an

44 Reischauer, Ennin's Diary. On Jōjin, see Borgen, 'San Tendai Godai san ki'; 'Jōjin's Travels from Center to Center'; and 'The Case of the Plagaristic Journal'.

45 Györekisho in $N B Z$ vol. 72, no. 572, 188-92.

46 Itō, ed., Matsuno'o taisha no shin'ei, 56-57, and 84-85. Still perhaps the most comprehensive study of Onjōji and Enchin is Miyagi Nobumasa and Tendaishū Jimon-ha Goonki Jimukyoku, Onjōji no kenkyū. A more readily available yet brief discussion of Enchin's travels in China can be found in Yoritomi Motohiro, Nicchū o musunda bukkyōsō, 149-60. 
incomplete understanding of not only medieval Japanese Buddhism, but also of East Asian Buddhist texts and the transmission of them.

Until I encountered the manuscript Buddhist canon held by Matsuo shrine in Kyoto, Japan, which was copied during the twelfth century and kept on site until the mid-nineteenth century in a building called the Godokyōjo 御読経所, I had never seen, nor even imagined, that anyone in East Asia vowed so-called Little Vehicle 小 乗部 (Hīnayāna), Śravakayāna, or non-Mahāyāna treatises. Yet the Ekottarāgama (Zengyi ahan jing 增一阿含經, $Z$ no. 770, $T$ no. 125) with fifty-one rolls and Samyuktāgama ( $Z a$ ahan jing 雜阿含經, $Z$ no. 771, T no. 99) with fifty rolls were vowed by chief shrine priest (kannushi) Hata no Yorichika 秦頼義 to the kami at Matsuo shrine on 1138.5.29-7.1 and 1138.5.30-7.8, respectively. Xuanzang's translation of the *Abhidharmanyāyānusāra-sástra in eighty rolls was vowed to the canon in the eleventh month of 1141 by Ryōkei 良慶, the abbot of Myōhōji 妙法寺, a temple in the southern valley of the shrine-temple precincts, and later vowed and added more scriptures between 1159 and $1165 .^{47}$

\section{Analysis and Context: Looking at history from an inverted chronological perspective}

The value of manuscripts is that they were not carefully selected and organized to present an idealized image of a tradition. Historians of East Asian Buddhism follow the great European Sinologists-many of whom translated the biographies or hagiographies of Faxian, Xuanzang, and Yijing - by carefully studying printed editions of Buddhist texts 版本學. If we seek to investigate communities who copied this literature for express purposes such as vowing an entire canon for the

47 Keyworth, 'Apocryphal Chinese books', 7, 18. Rolls 2176-2221 (colophons 892-916) are from the Ekottarägama ( $Z$ no. 770, $T$ no. 125); rolls 22222262 (colophons 917-941) are from the Samyuktāgama ( $Z$ no. 771, $T$ no. 99); and rolls 3046-3117 (colophons 1065-1132). See Nakao and Myōrenji, 'Matsuosha issaikyō', 263-67, 275-81. 
protection-or sublimation-of particular deities, whether these are considered Indian, Chinese, Japanese, or even Korean in the case of the kami enshrined at Matsuo, then manuscripts like the ones we examined here can provide information that may not make much sense. Why, for example, did Hata no Yorichika vow the Ekottarāgama, Samyuktāgama, or Xuanzang's translation of the *Abhidharmanyāyānusāra-sástra? This was possibly because it was important for the Hata clan to sustain the comprehensiveness of the canon preserved on site within the Godokyōjo. In that case, what happened to the Huili and Yancong's biography of Xuanzang? Why are this and Record of a Journey to the Western Regions not in the canon as we have it today? Perhaps the hypothesis this paper provides is an inverted one: I suspect that these texts are not missing because of excessive use or tendoku 転読 practice, in which they recited only key passages from the beginning, middle, and end of a chapter or perhaps only titles.

There is a clue to this and several of the other questions I raised in a colophon to rolls twenty-nine and thirty of the Zhenyuan lu, which shows that the seven-hall temple of Mount Tōen (Tōenzan Nanatsudera 稲園山七寺), a Chizan Shingonshū 智山真言宗 temple today, was part of Atsuta jingüji when governor of Owari 尾張 county, Ōnakatomi no Yasunaga 大中臣安長, vowed more than 300 rolls between 1175-1178; the work was interrupted in $1180 .{ }^{48}$ The colophon reveals that the copyist or scribe checked with manuscripts from Fushimi [Inari shrine] 伏見稲荷大社 (in red to the left), Bonshakuji 盆釈寺 (a Tendai scriptorium, with a black circle), and Hosshōji (in red and to the right), which was significantly enlarged and supported by Emperor Shirakawa in $1077 .{ }^{49}$ These collation notes are

48 Ochiai, Girard, and Kuo, 'Découverte de manuscrits bouddhiques chinois au Japon', 370. Please note that the Kongōji canon was also apparently vowed to the daimyōjin of a chinjusha of Mount Kōya: Kōyasan Tennomiya 高野山天野 宮. See rolls 003-33, 0073-001 ( $Z$ no. 73), 411-001, 411-001, 514-001 as examples in Ochiai, ed., Kongōji issaikyō.

49 Makita et al., eds., Chūgoku senjutsu kyōten, 441, 59-65; Akao Eikei, 'Koshakyō', 797-809. Cf. Miyabayashi and Ochiai, 'Nanatsudera', 116 also notes that the catalog from Kiyomizudera of these rolls was checked. 
an important discovery that connects the Nanatsudera and Matsuo canons: these rolls of the Zhenyuan $l u$ were vowed to fifteen avatāras or manifestations (gongen 権現) of the principal kami of Atsuta, Yatsurugi no daimyōjin 八剱大明神, at sites including the Naikū and Gekū 内外宮 of Ise 伊勢神宮, three sites at Kumano 熊野本宮大社 (Hongū 本宮, Shingū 新宮, Nachi 那智), the three sages of Hiyoshi 日吉社 (shrine on Mount Hiei), and Tsushima 津島, and Nangū 南 宮 shrines in the Owari region (Aichi prefecture). Both Nanatsudera and Matsuo canons were apparently copied for kami tied to the imperial lineage or centers of ritual power. It would appear that either the priests or monks at these shrine-temple complexes were not as enthralled with Xuanzang as they were with Faxian and Yijing, or that Xuanzang was seen as more of an eminent translator than he was an exemplary pilgrim who went on a quest in search of sacred scriptures.

I argued in this paper that one of the reasons we are unable to clearly see this perspective is because the editors of the Taisho made some peculiar editing decisions. For instance, they separate the biographies of these three eminent pilgrims. Perhaps, as Max Deeg, among others, has shown, it may very well have been a keen, Protestant-and Counter-Reformation-obsession with the origins of all things, and especially religion, that drove the pronounced interest in translating Faxian's autobiography in nineteenth to twentieth century Europe. ${ }^{50}$ Despite the many ways Chinese and Japanese Buddhists emulated key aspects of what Gregory Schopen called Protestant presuppositions in the study and practice of Buddhism during the late nineteenth and early twentieth centuries, to the best of my knowledge, there was no countervailing emphasis on Faxian in East Asia. ${ }^{51}$ Rather, unlike in European language studies of East Asian Buddhism, which I contend Arthur Waley's masterful The Read Tripitaka surely is, we tended to abide by demarcated periodization schemes (panjiao 判教, for example) and see beyond the order of the canons, whether printed editions, manuscript canons, or fragments

50 Deeg, 'Has Xuanzang really been in Mathurā?'; Das Gaoseng-FaxianZhuan, 51.

51 Schopen, 'Archaeology'. 
in a hidden abandoned library, to restrict the perspectives through which we examine the agents who transmitted these sacred texts through the ages.

Part of the problem may not have much to do with Faxian, Xuanzang, or Yijing in terms of either their status as eminent monk-pilgrims or even as translators, but instead may have to do with the concept of legacy. The Oxford English Dictionary gives us several ways to think about legacy. Etymologically derived from French or Latin, when used as a noun, a legacy refers to a body of delegates or legates or even papal legates (as in on behalf of the Roman Catholic Pope) who are sent in legacy of an authority or authoritative group to speak in an official capacity with other legates, delegates, and so on. ${ }^{52}$ It is difficult to conceive of any two Chinese Buddhist monastics other than Xuanzang and Faxian who posthumously played such a pivotal role as, for example, spreading the teachings of Buddhism to Japan or Korea. The word 'spread' brings me to another meaning of the word legacy: the act or action of bequeathing. With connotations that complement the English word 'bequeath' in terms of inheritance after the death of a family member, in Mandarin Chinese we might opt for the term yizeng 遺贈 to translate bequeath. Yet in Japanese, the verb tsutaeru 伝える circles back to the crucial post-mortem role Yijing, Xuanzang, and Faxian played in the transmission of Buddhism. Buttressed as the penultimate Chinese eminent monk within multiple narratives of transmission, it is what Faxian transmitted or, more importantly, what he and especially Xuanzang, but also Yijing, are understood to have transmitted long after they deceased which seems to have determined their status within the history of East Asian Buddhism.

Perhaps it is time for scholars who investigate the history of East Asian Buddhism-and particularly the literary corpus we rather audaciously refer to in English as the Buddhist canon or da zangjing 大藏經 (lit. great storehouse of scriptures or classics) in Chinese-to pay more attention to one of the more pressing questions posed by

52 'Legacy' in OED, third ed., 2016: http://www.oed.com/view/Entry/107006? rskey=j23SzI\&result=1\# eid, accessed February 2019. 
our colleagues who work in the field of Jewish and Christian studies: is it vituperative to refer to the canonical collection of Jewish scriptures in Biblical Hebrew with some Aramaic, the Tanak (Tanakh), as the Old Testament? Should we, instead, refer to it as the Hebrew Bible? 'Old Testament' suggests that there must be a corresponding New Testament, and mistakenly implies that the Jewish Tanak is the same thing as the Christian Old Testament and is therefore obsolete. Whereas the Tanak consists of twenty-four books (Pentateuch [Torah], Nevi'im, and Ketuvim), the Catholic, Anglican, and Orthodox Christian Old Testaments, for example, include additional books considered apocryphal, deuterocanonical, or as pseudepigrapha (e.g., Judith, Baruch, Wisdom of Solomon, Maccabees, Enoch, etc.), which are not part of the Hebrew Bible, and yet were preserved in the Septuagint (Greek translation of an early Hebrew Bible). Different vocabularies, punctuation, canonical order, and emphases separate Masoretic manuscripts from the Vulgate and later derivatives. Furthermore, can there be a New Testament without an Old Testament, out of which, presumably, we can trace the legacy and multiple narratives of a singular Judeo-Christian tradition? What may be most important for specialists in the study of East Asian religions to bear in mind is what J. Z. Smith refers to as 'the relative economy of the library (bibliotheca)' that stimulates these deliberations: 'One thinks, by way of contrast, of the Ming Daoist canon with its 1607 supplement, which contains 1,487 separate texts, or the already noted Chinese Buddhist Canon $(84,000)$, and distinctive Tibetan collections totaling 4,681 titles'. ${ }^{53}$ Smith cites Lewis Lancaster on the contents of the Tibetan $b K a$ ' 'gyur and the bsTan 'gyur, and Nanjō Bunyū 南 条文雄 (1849-1927) and Friedrich Max Müller (1823-1900) for the ' 84,000 ' texts in the Chinese Buddhist canon. ${ }^{54}$ Just because there are many more sacred books in the various Buddhist canons than in, for

\footnotetext{
53 Smith, 'Religion and Bible', especially 17.

54 Smith cites Lancaster, 'Buddhist Literature'; see also 'Editing Buddhist Texts' on the Tibetan canon. For the Chinese, he cites Müller, Introduction to the Science of Religion, 114, note 10 and suggests that the brochure, English Translation Project, 2, corroborates the claim of 84,000 texts. 84,000 far exceeds the
} 
example, the Tanak (Tanakh) or the Bible, this does not mean that the order of the books is any less significant for Buddhists than it is for Jews or Christians. Whether in Hebrew, Greek, Latin, French, German, or English, Genesis comes first in both the Tanak and the Bible, and it appears to have been this way for a long, long time. Perhaps the same can be said for the order of the East Asian Buddhist canon(s), which warrant further scrutiny.

Jerome (347-420), who translated the Septuagint from Greek into Latin, the Vulgate, was a contemporary of Faxian. Like Jerome, Faxian's notoriety appears to be eclipsed by posterity. Nearly all signs point to the fact that he was surpassed in almost every conceivable way by Xuanzang. Whereas Faxian spent only slightly less time away on his quest than Xuanzang did (399-412 or 413 versus 629-645), the 1335 rolls of seventy-five different titles that Xuanzang translated from Sanskrit manuscripts seems to have cemented his preeminence. Yet when we look more closely at manuscripts in whose hands we can determine the context for their production and several plausible uses, some of which are almost certainly religious, it may very well have been Faxian's status as a pilgrim, first and foremost, that inspired medieval Japanese as much or more than Yijing or Xuanzang.

\section{Bibliography}

\section{Abbreviations}

BD Dunbuang Baozang 敦煌寶藏. See Bibliography, Sources, Dunbuang Baozang.

Dx. or F. Dunhuang manuscript collection at the St. Petersburg Branch of the Institute of [дx and $\phi$ ] Oriental

Studies, Russian Academy of Sciences. Facsimile ed.

actual number of separate texts contained in any version of a Buddhist canon, and instead represents an immeasurable or all-inclusive number of the historical Buddha's teachings, earthly desires, or even the number of stūpas King Aśoka (r. ca. 268-232 BCE) is said to have had built. 
See Bibliography, Sources, Dunhuang manuscript collection.

NBZ Dai Nibon bukkyōzensho 大日本佛教全書. See Bibliography, Sources, Dai Nibon bukkyō zensho.

P. Pelliot collection of Dunhuang manuscripts. See Bibliography, Sources, Pelliot collection of Dunhuang manuscripts.

S. Stein collection of Dunhuang Manuscripts. See Bibliography, Sources, Stein collection of Dunhuang Manuscripts.

T Taishōshinshū daizōkyōo 大正新脩大蔵経. See Bibliography, Sources, Takakusu and Watanabe, eds.

\section{Sources}

Abé, Ryūichi. 'Scholasticism, Exegesis, and Ritual Practice: On Renovation in the History of Buddhist Writings in the Early Heian Period'. In Heian Japan, Centers and Peripheries, edited by Mikael S. Adolphson, Edward Kamens and Stacie Matsumoto, 179-211. Honolulu: University of Hawai'i Press, 2007.

- - . The Weaving of Mantra: Kükai and the Construction of Esoteric Buddhist Discourse. New York: Columbia University Press, 1999.

Abe Yasurō 阿部康朗. Chūsei Nihon no shūkyō tekusuto taikei 中世日 本宗教テクスト体系 [The System of Medieval Japanese Religious Texts]. Nagoya: Nagoya daigaku shuppankai 名古屋大学出版会 [Nagoya University Press], 2013.

Adolphson, Mikael S. The Teeth and Claws of the Buddha: Monastic Warriors and Sōhei in Japanese History. Honolulu: University of Hawai'i Press, 2007.

Akao Eikei 赤尾栄慶. 'Koshakyō shi kara mita Nanatsudera issaikyō: shoshigakuteki apurocchi o chūshin ni’ 古写経史から見た七寺 一切経一一書誌学的アプローチを中心に [History of Ancient Manuscripts seen from the Buddhist Canon at the Nanatsu Temple: Centering around the Bibliographical Approaches]. In Chügoku Nibon senjutsu kyōten 中国撰述経典 [Scriptures and Commentaries Composed in China and Japan], edited by Ochiai 
Toshinori 落合俊典, Okabe Kazuo 岡部和雄, Sueki Fumihiko 末小文美士, Miyake Tetsujō 三宅徹誠, Kinugawa Kenji 衣川賢 次, Makino Kazuo 牧野和夫, Saitō Takanobu 斉藤隆信, et al. Nanatsudera koitsu kyōten kenkyū sōsho 七寺古逸経典研究叢書 [The Long Hidden Scriptures of Nanatsudera, Research series], 789-810. Tokyo: Daitō shuppansha 大東出版社, 2000.

Beal, Samuel. Si-yu-ki, Buddhist Records of the Western World, by

Hiuen Tsiang. 2 vols. Delhi: Oriental Books Reprint Corp, 1969.

First published 1884 by Trübner (London).

- - . Travels of Fab-Hian and Sung-Yun, Buddhist pilgrims, from

China to India (400 A.D. and 518 A.D.). London: Trübner, 1869. Bielefeldt, Carl. 'Kokan Shiren and the Sectarian Uses of History'.

In The Origins of Japan's Medieval World: Courtiers, Clerics, Warriors, and Peasants in the Fourteenth Century, edited by Jeffrey P. Mass, 295-317. Stanford: Stanford University Press, 1997. Borgen, Robert. 'The Case of the Plagaristic Journal: A Curious Passage from Jōjin’s Diary'. In New Leaves: Studies of Japanese Literature in Honor of Edward G. Seidensticker, edited by Aileen Gatten and Anthony Hood Chambers, 63-88. Ann Arbor: Center for Japanese Studies, University of Michigan, 1993.

- - - 'Jōjin's Travels from Center to Center (with some Periphery in between)'. In Heian Japan, Centers and Peripheries, edited by Mikael S. Adolphson, Edward Kamens and Stacie Matsumoto, 384-414. Honolulu: University of Hawai'i Press, 2007.

- - - 'San Tendai Godai san ki as a Source for the Study of Sung History'. Bulletin of Sung-Yüan Studies 19 (1987): 1-16.

Buswell, Robert E., Jr. 'Sugi's Collation Notes to the Koryŏ Buddhist Canon and Their Significance for Buddhist Textual Criticism'. In Scripture: Canon, Text, Context: Essays Honoring Lewis R. Lancaster, edited by Richard K. Payne, 57-118.

Berkeley: Institute of Buddhist Studies and BDK America, 2014. Buswell, Robert E. Jr., and Donald S. Jr. Lopez. The Princeton Dictionary of Buddhism. Princeton: Princeton University Press, 2014.

Chavannes, Édouard. Mémoire composé à l'époque de la grande dynastie T'ang sur les religieux éminents qui allèrent chercher la loi dans les pays d'Occident par I-tsing [Memoir written by I-Tsing 
during the Grand Tang Dynasty on eminent monks who went in search of the Law in the Western countries]. Paris: E. Leroux, 1894.

Dai Nibon bukkyōzensho 大日本佛教全書 [Complete Buddhist Works of Japan]. 150 vols. Tokyo: Bussho kankōkai 佛書刊行會, 1912-1922. All references are to the rpt. ed., 100 vols. Suzuki Gakujutsu Zaidan 鈴木学術財団 (Tokyo: Kōdansha 講談社, 1970-1973).

Deeg, Max. Das Gaoseng-Faxian-Zhuan als religionsgeschichtliche Quelle: der älteste Bericht eines chinesischen buddhistischen Pilgermönchs über seine Reise nach Indien mit Übersetzung des Textes [The Gaoseng Faxian zhuan as a Source for the History of Religion: The Oldest Record of a Chinese Buddhist Pilgrim Monk on his Journey to India with Translation of the Text]. Studies in Oriental Religions 52. Wiesbaden: Otto Harrassowitz, 2005.

- - - 'Has Xuanzang really been in Mathurā? Interpretatio Sinica or Interpretatio Occidentalia-How to Critically Read the Records of the Chinese Pilgrim'. In Essays on East Asian Religion and Culture: Festschrift in honour of Nishiwaki Tsuneki on the occasion of his 65th birthday 東アジアの宗教と文化: 西脇常記教授 退休記念論集 [Editorial committee for the Festschrift in honour of Nishiwaki Tsuneki], edited by Christian Wittern and Shi Lishan, 388- 426. Kyoto, 2007.

Deleanu, Florin. 'The Transmission of Xuanzang's Translation of the Yogācārabhūmi in East Asia: With a Philological Analysis of Scroll XXXIII'. In Kongōji issaikyō no sōgōteki kenkyū to Kongōji shōgyō no kisoteki kenkyū 金剛寺一切経の総合的研究と金剛寺聖 教の基礎的研究 [Heisei 16 18 nendo kagaku kenkyūhi hojokin kiban kenkyū (A) kenkyū seika hōkokusho] 平成 16 18 年度 科学研究費補助金基盤研究 (A) 研究成果報告書 [2004-2006 Grant-in-Aid Scientific Research (category A) Research Report vol. 1], edited by Ochiai Toshinori, 1-44, 632-589. Tokyo: Kokusai Bukkyōgaku daigakuin daigaku 国際仏教大学院大学 [International College for Postgraduate Buddhist Studies], 2007.

Demiéville, Paul, Hubert Durt, Anna K. Seidel, and Académie des inscriptions \& belles-lettres (France). Répertoire du canon bouddhique sino-japonais, édition de Taishō (Taishō Shinshū Daizökyō): [fascicule annexe du Höbögirin] [Repertoire of the 
Sino-Japanese Buddhist Canon, Taishō Edition]. Revised and augmented edition. Paris: Librairie d'Amerique et d'Orient, 1978.

Dunbuang Baozang 敦煌寶藏 [Treasured Collection of Dunhuang Scriptures]. 140 vols. Edited by Huang Yongwu 黄永武. Taipei: Xinwenfeng chuban gongsi 新文豐出版公司, 1981-1986.

Dunhuang manuscript collection at the St. Petersburg Branch of the Institute of [ax and $\phi$ ] Oriental Studies, Russian Academy of Sciences. Facsimile ed. Ecang Dunbuang wenxian 俄藏敦煌文 獻, 17 vols. Shanghai: Shanghai guji chubanshe 上海古籍出版社, 1992-2001.

Forte, Antonino. 'The Relativity of the Concept of Orthodoxy in Chinese Buddhism: Chih-sheng's indictment of Shih-li and the Proscription of the Dharma Mirror Sutra'. In Chinese Buddhist Apocrypha, edited by Robert E. Buswell, Jr. and Robert M. Gimello, 239-49. Honolulu: University of Hawai' i Press, 1990. Funayama Tōru 船山徹. Butten wa dou kanyaku sareta no ka: suutora ga kyōten ni naru toki 仏典はどう漢訳さらたのかースートラが 経典になるとき [Making Sūtras into 'Classics': How Buddhist Scriptures Were Translated into Chinese]. Tokyo: Iwanami shoten 岩波書店, 2013.

Gakujutsu Furontia jikkō iinkai 学術フロンティア実行委員会, ed. Nihon genson hasshu issaikyō taishō mokuroku tsuke Tonkō bukkyo bunken 日本現存八種一切経対照目録 [付] 敦煌仏教文 献 [Comparative Catalog of Scriptures in eight Old Japanese Manuscript Buddhist Canons cross references with Buddhist Literature from Dunhuang]. Tokyo: Kokusai bukkyōgaku daigakuin daigaku 国際仏教大学院大学 [International College for Postgraduate Buddhist Studies], 2006.

Giles, Herbert A. Record of the Buddhistic Kingdoms: Translated from the Chinese. London: Trübner \& Co., 1877.

Grapard, Allan. 'Institution, Ritual, and Ideology: The Twenty-Two Shrine-Temple Multiplexes of Heian Japan'. History of Religions 27, no. 3 (1988): 246-69.

Grapard, Allan G. The Protocol of the Gods: A Study of the Kasuga cult in Japanese History. Berkeley: University of California Press, 1992. Huang Yanjun 黃延軍. Zhongguo guojia tushuguancang Xixiawen Da bore boluomiduo jing yanjiu 中國國家圖書館藏西夏文《大 
般若波羅蜜多經》研究 [A Study of the Mahāprajñāpāramitāsütra in Tangut in the archives of the Chinese National Library]. Edited by Huang Jianming 黄建明. 2 vols. Beijing: Minzu chubanshe, 2012.

Iida Takehiko 飯田剛彦. 'Shōgōzō kyōkan “Jingo keiun ni nen gogangyō” ni tsuite’ 聖語蔵経卷「神護景雲二年御願経」について [On the manuscripts in the Shōgozō repository from the wowed canon of 768]. Shōsōin kiyō 正倉院紀要 [Bulletin of Office of the Shōsōin Treasure House], no. 34 (2012-2013): 210-161.

Itō Shirō 伊東史朗, ed. Matsuno'o taisha no shin'ei 松尾大社の神影 [Matsuno'o Taisha Shrine: The Spread of Shinto Art from Ancient Times]. Osaka: Matsuno'o Taisha, Fukamoto Publishers, 2011. Iwamoto Taketoshi 岩本健寿. 'Nagaya no ōkimi hotsugankyō (zō wadō kyō) denraikō’ 長屋王発願経 [蔵和銅経] 伝来考 [Preliminary study of Prince Nagaya's vowed scriptures from the Wadō period]. In Bukkyō bunmei no tenkai to byōgen moji, gengo, zōkei to shisō 仏教文明の転回と表現文字・言語・造形・ 思想 [Turns of Buddhist Civilization and Expressing Writings, Language, Modeling, and Thought], edited by Shinkawa Tokio 新川登亀男, 209-36. Tokyo: Bensei shuppan 勉誠出版, 2015. Keyworth, George A. 'Apocryphal Chinese books in the Buddhist canon at Matsuo Shintō shrine'. Studies in Chinese Religions 2, no. 3 (2016): 281-314.

Klaproth, Julius Heinrich, Ernest Augustin Xavier Clerc de Landresse, and Jean Pierre Abel Rémusat. Foé Koué Ki, ou Relations des royaumes bouddhiques: voyage dans la Tartarie, dans l'Afghanistan et dans l'Inde, exécuté, à la fin du IVe siècle, par Chy Fa Hian [Foe Koue Ki or Relations of Buddhist Kingdoms: A voyage in Tatary, Afghanistan and in India, executed at the end of the fourth century, by Chy Fa Hian]. Paris: Imprimerie Royale, 1836.

Kokusai bukkyōgaku daigakuindaigaku fuzokutoshokan 国際仏教 学大学院大学付属図書館. Taishōzō Tonkō shutsudo Butten taishō mokuroku Zantei daisanban 大正蔵・敦煌出土仏典対照目録 暫定3版 [A Concordance to the Taishō Canon and Dunhuang Buddhist Manuscripts, Third Provisional Edition]. Tokyo: Kokusai bukkyōgaku daigakuindaigaku fuzokutoshokan 国 際仏教学大学院大学付属図書館 [International College for 
Postgraduate Buddhist Studies Library], 2015.

Lancaster, Lewis. 'Buddhist Literature: Its Canons, Scribes, and

Editors'. In The Critical Study of Sacred Texts, edited by Wendy

Doniger, 215-29. Berkeley: Graduate Theological Union, 1979.

- - - 'Editing Buddhist Texts'. In Buddhist Thought and Asian

Civilization: Essays in Honor of Herbert V. Guenther on His

Sixtieth Birthday, edited by Leslie S. Kawamura and Keith Scott,

141-51. Emeryville: Dharma Publishing, 1977.

Lancaster, Lewis R., and Sung-bae Park, eds. The Korean Buddhist

Canon: A Descriptive Catalogue. Berkeley: University of

California Press, 1979.

Legge, James. A Record of Buddhistic Kingdoms Being an Account by the

Chinese Monk of His Travels in India and Ceylon (A.D. 399-414)

in Search of the Buddhist Books of Discipline. Oxford: Clarendon

press, 1886. Reprint, New York: Dover Publications, 1991.

Lowe, Bryan. 'Buddhist Manuscript Cultures in Premodern Japan'.

Religion Compass 8, no. 9 (2014): 287-301.

- - _. 'Contingent and Contested: Preliminary Remarks on

Buddhist Catalogs and Canons in Early Japan'. Japanese Journal

of Religious Studies 41, no. 2 (2014): 221-53.

- _- 'The Discipline of Writing: Scribes and Purity in Eighth-

Century Japan'. Japanese Journal of Religious Studies 39, no. 2 (2012): 201-39.

Makita Tairyō 牧田諦亮, Ochiai Toshinori 落合俊典, Yang Zengwen 楊曾文, Yao Changshou 姚長壽, Naomi Gentetsu 直海玄哲, Kōfuku Kaori 幸福香織, Miyai Rika 宮井里佳, and Enomoto Masaaki 榎本正明, eds. Chūgoku senjutsu kyōten 中国撰述経 典 [Scriptures Compiled in China]. 6 vols. Vol. 1, Nanatsudera koitsu kyōten kenkyū sōsho 七寺古逸経典研究叢書 [The Long Hidden Scriptures of Nanatsudera, Research series]. Tokyo: Daitō shuppansha 大東出版社, 1994.

Minowa Kenryō 蓑輪顕量, and Paul Groner. 'The Tendai Debates of 1131 at Hosshōji'. Japanese Journal of Religious Studies 41, no. 1 (2014): 133-51.

Miyabayashi Akihiko 宮林昭彦, and Ochiai Toshinori 落合俊典. 'Zhenyuan xinding shijiao mulu juandi 29-30' 貞元新定釋 教目錄 巻第 29-30 [Catalogue for the Buddhist Texts Newly 
Compiled under the Zhenyuan Era (785-805)]. In Chügoku Nihon kyōten shōsho mokuroku 中國・日本經典章疏目録 [Catalogues of Scriptures and their Commentaries in China and Japan], edited by Makita Tairyō 牧田諦亮, Antonino Forte, Miyabayashi Akihiko 宮林昭彦, Ochiai Toshinori 落合俊典, Saitō Takanobu 齋藤隆信, Miyazaki Kenji 宮崎健司, Kajiura Susumu 梶浦晋, Ōuchi Fumio 大内文雄 and Gregor Paul. Nanatsudera koitsu kyōten kenkyū sōsho 七寺古逸経典研究叢書, 59-128. Tokyo: Daitō shuppansha 大東出版社, 1998.

Miyagi Nobumasa 宮城信雅, and Tendaishū Jimon-ha Goonki Jimukyoku 天台宗寺門派御遠忌事務局. Onjoji no kenkyū 園城 寺之研究 [A Study of Onjōji]. Ōtsu-shi: Urisabakijo hoshino shoten 賣別所星野書店, 1931. Kyoto: Shibunkaku 思文閣, 1978. Müller, Friedrich Max. Introduction to the Science of Religion: Four Lectures Delivered at the Royal Institution; With Two Essays, On False Analogies and The Philosophy of Mythology. London: Longmans, Green \& Co., 1873.

Nakao Takashi 中尾堯, and Honmon Hokkeshū Daihonzan Myōrenji 本門法華宗大本山妙蓮寺, eds. Kyōto Myōrenji zō 'Matsuosha issaikyo' chōsa hökokusho 京都妙蓮寺蔵「松尾社一切 経」調査報告書 [Written Report Investigating the Matsuo Shrine (Buddhist) Canon, held by Myōren Temple in Kyoto]. Tokyo: Ōtsuka kōgeisha 大塚巧藝社, 1997.

Nara National Museum 奈良国立博物館, ed. Special Exhibit of Ancient Sutras from the Heian Period: Encountering the Legendary Kunōji Sutras. Nara: Nara Kokuritsu Hakubustukan 奈良国立博物館, 2015.

Nibon jinmei daijiten 日本人名大辞典 [Large Dictionary of [Historical] Japanese People]. Tokyo: Kōdansha 講談社, 2001. Ochiai Toshinori 落合俊典 ed. Kongōji issaikyō no sōgōteki kenkyū to Kongōji shōgyō no kisoteki kenkyū 金剛寺一切経の総合的研 究と金剛寺聖教の基礎的研究 [Heisei 16 18 nendo kagaku kenkyūhi hojokin kiban kenkyū (A) kenkyū seika hōkokusho] 平成 16 18 年度科学研究費補助金基盤研究 (A) 研究成果報告 書 [2004-2006 Grant-in-Aid Scientific Research (category A) Research Report vol. 1], 2 vols. Tokyo: Kokusai Bukkyōgaku daigakuin daigaku 国際仏教大学院大学 [International College 
for Postgraduate Buddhist Studies], 2007.

Ochiai Toshinori, Frédéric Girard, and Li-ying Kuo. 'Découverte de manuscrits bouddhiques chinois au Japon [Conférence prononcée par Monsieur Ochiai Toshinori]'. Bulletin de l'École française d'Exrême-Orient [Bulletin of the French School of the Far East] 83 (1996): 368-75.

Pelliot collection of Dunhuang manuscripts (Bibliothèque Nationale, Paris). International Dunhuang Project online database http://idp.bl.uk. References to Pelliot chinois unless otherwise noted; e.g., P. Tib.

Pruden, Leo. 'The Hasshu koyo by the Scholar Monk Gyonen (1240-1321)'. Pts. 1 and 2. Pacific World: Journal of the Institute of Buddhist Studies n.s., no. 7 (Fall 1991): 53-67; no. 8 (Fall 1992):61-83.

Rong Xinjiang. 'The Nature of the Dunhuang Library Cave and the Reasons for its Sealing'. Cabiers d'Extrême Asie [East-Asian Journal] 11, no. 1 (1999): 247-75.

Sagai Tatsuru 嵯峨井建. Shinbutsu shūgō no rekishi to girei kūkan 神仏習合の歴史と儀礼空間 [History of Shintō-Buddhist Syncretism and Ritual Space]. Kyoto: Shibunkaku shuppan 思文 閣出版, 2013.

Sakaehara Towao 栄原永遠. Shōsōin monjo nyümon 正倉院文書入門 [Guide to the Literary Documents Contained in the Shōsōin]. Tokyo: Kadokawa gakujutsu shuppan 角川学術出版, 2011.

Sango, Asuka. 'Buddhist Debate and the Production and Transmission of Shōgyō in Medieval Japan'. Japanese Journal of Religious Studies 39, no. 2 (2012): 241-73.

- - . The Halo of Golden Light: Imperial Authority and Buddhist Ritual in Heian Japan. Honolulu: University of Hawai'i Press, 2015.

Schopen, Gregory. 'Archaeology and Protestant Presuppositions in the Study of Indian Buddhism'. In Bones, Stones, and Buddhist Monks: Collected Papers on the Archaeology, Epigraphy, and Texts of Monastic Buddhism in India, edited by Gregory Schopen, 1-22. Honolulu: University of Hawai'i Press, 1997.

Smith, Jonathan Z. 'Religion and Bible'. Journal of Biblical Literature 128, no. 1(2009): 5-27. 
Solonin, Kirill. 'The Glimpses of Tangut Buddhism'. Central Asiatic Journal 52, no. 1 (2008): 64-127.

Stanislas, Julien. Histoire de la Vie de Hiouen-Thsang et de ses voyages dan l'Inde, depuis l'an 629 jusqu'en 645 [History of the life of Hiouen-Thsang and his travels in India, from the year 629 to 645]. Paris: Impr. impériale, 1853. Reprint, New York: Johnson Reprint Corp., 1968.

Stein collection of Dunhuang manuscripts (British Library, London). International Dunhuang Project online database http://idp.bl.uk.

Strickmann, Michel, and Bernard Faure. Chinese Magical Medicine. Asian Religions and Cultures. Edited by Bernard Faure and Carl Bielefeldt. Stanford: Stanford University Press, 2002.

Sueki Fumihiko 末木文美士, Shimoda Masahiro 下田正弘, and Horiuchi Shinji 堀内伸二, eds. Bukkyōno jiten 仏教の事典 [Encyclopedia of Buddhism]. Tokyo: Asakura shoten 朝倉書店, 2014.

Takakusu Junjirō. Record of the Buddhist Religion as Practised in India and the Malay Archipelago (A.D. 671-695) by I-tsing. London: Clarendon Press, 1896.

Takakusu Junjirō 高楠順次郎, and Watanabe Kaigyoku 渡邊海 旭, eds. Taishō shinshū daizōkyō 大正新脩大藏経. 100 vols. Tokyo: Taishō issaikyō kankōkai 大正一切経刊行, 1924-1932. Rpt., Chinese Buddhist Electronic Texts Association 中華 電子佛典協會, CBETA Electronic Tripitaka Collection 電子 佛典集成, Taipei: 1998-2019. http://cbetaonline.dila.edu. tw. SAT Daizōkyō Database ver. 2018. Accessed Mar. 2019. http://21dzk.l.u-tokyo.ac.jp/SAT/index_en.html.

Tucci, Giuseppe. Rin-chen-bzan-po and the Renaissance of Buddhism in Tibet around the Millennium. Translated by Nancy Kipp Smith and Thomas J. Pritzker. Indo-Tibetica II. Edited by Lokesh Chandra. New Delhi: Aditya Prakashan, 1988. Originally published as Indo-tibetica II: Rin c'en bzan po e la rinascita del buddhismo nel Tibet intorno al Mille. Roma: Reale Accademia d'italia, 1933.

van Schaik, Sam. 'The Uses of Implements are Different: Reflections on the Functions of Tibetan Manuscripts'. In Tibetan 
Manuscript and Xylograph Traditions: The Written Word and Its Media within the Tibetan Cultural Sphere, edited by Orna Almogi, 221-42. Hamburg: Department of Indian and Tibetan Studies, Universität Hamburg, 2016.

Waley, Arthur. The Real Tripitaka, and Other Pieces. London: Allen and Unwin, 1952.

Watters, Thomas. On Yuan Chwang's Travels in India 629-645 A.D. Oriental Translation Fund New Series XIV-XV, edited by T. W. Rhys Davids and S. W. Bushell, 2 vols. London: Royal Asiatic Society, 1904-1905.

Weinstein, Stanley. 'Chinese Buddhism'. In Vol. 2 of Encyclopedia of Religion, edited by Mircea Eliade et al., 482-87. New York: Macmillan Press, 1987.

Wu Cheng'en, and Anthony C. Yu. Journey to the West, Revised Edition, Volume 4. Chicago: University of Chicago Press, 2012.

Wu, Jiang. 'From the "Cult of the Book" to the "Cult of the Canon": A Neglected Tradition in Chinese Buddhism'. In Spreading the Buddha's Word in East Asia: The Formation and Transformation of the Chinese Buddhist Canon, edited by Jiang Wu and Lucille Chia, 16-46. New York: Columbia University Press, 2016.

Wu, Jiang, and Lucile Chia, eds. Spreading the Buddha's Word in East Asia: The Formation and Transformation of the Chinese Buddhist Canon. New York. Columbia University Press, 2016. Yoritomi Motohiro 頼富本宏. Nitchū o musunda bukkyōsō: hatōo koete kesshi no tokai 日中を結んだ仏教僧: 波濤を超えて決死の渡 海 [Connections between Chinese and Japanese Buddhist Monks who Crossed the Surging Sea Prepared for Death]. Zusetsu Chūgoku bunka hyakka 図説・中国文化百華 08 [Illustrated Hundred Flowers of Chinese Culture]. Tokyo: Nōsan Gyoson bunkakyōkai 農山漁村文化協会, 2009. 